\title{
Revefenacin Absorption, Metabolism, and Excretion in Healthy Subjects and Pharmacological Activity of Its Major Metabolite ${ }^{\mathrm{S}}$
}

\author{
David L. Bourdet, Suresh Yeola, Sharath S. Hegde, Pierre-Jean Colson, Chris N. Barnes, \\ and Marie T. Borin
}

Theravance Biopharma US, Inc., South San Francisco, California (D.L.B., S.Y., S.S.H., P.-J.C., C.N.B., M.T.B)

Received May 1, 2020; accepted August 21, 2020

\section{ABSTRACT}

Revefenacin inhalation solution is an anticholinergic indicated for the maintenance treatment of patients with chronic obstructive pulmonary disease. Mass balance, pharmacokinetics, and metabolism of revefenacin were evaluated after intravenous and oral administration of $\left[{ }^{14} \mathrm{C}\right]-$ revefenacin in healthy subjects. Pharmacological activity of the major revefenacin metabolite was also assessed. Adult males $(n=9)$ received $20 \mu \mathrm{g}$ intravenously of approximately $1 \mu \mathrm{Ci}\left[{ }^{14} \mathrm{C}\right]$-revefenacin and/or a single $200-\mu \mathrm{g}$ oral solution of approximately $10 \mu \mathrm{Ci}\left[{ }^{14} \mathrm{C}\right]$-revefenacin. Mean recovery of radioactive material was $\mathbf{8 1 . 4 \%}$ after intravenous administration (54.4\% in feces; $\mathbf{2 7 . 1} \%$ in urine) and $\mathbf{9 2 . 7 \%}$ after oral dosing $(\mathbf{8 8 . 0} \%$ in feces, $4.7 \%$ in urine). Mean absolute bioavailability of oral revefenacin was low $(\mathbf{2 . 8 \% )}$. Intact revefenacin accounted for approximately $52.1 \%$ and $13.1 \%$ of the total radioactivity in plasma after intravenous and oral administration, respectively. Two main circulating metabolites were observed in plasma. After an intravenous dose, a hydrolysis product, THRX-195518 (M2) was observed that circulated in plasma at $\mathbf{1 4 . 3} \%$ of total radioactivity. After an oral dose, both THRX-195518 and THRX-697795 (M10, N-dealkylation and reduction of the parent compound) were observed at $12.5 \%$ of total circulating radioactivity. THRX-195518 was the major metabolite excreted in feces and comprised $18.8 \%$ and $9.4 \%$ of the administered intravenous and oral dose, respectively. The major metabolic pathway for revefenacin was hydrolysis to THRX-195518. In vitro pharmacological evaluation of THRX195518 indicated that it had a 10-fold lower binding affinity for the $M_{3}$ receptor relative to revefenacin. Receptor occupancy analysis suggested that THRX-195518 has minimal contribution to systemic pharmacology relative to revefenacin after inhaled administration.

\section{SIGNIFICANCE STATEMENT}

The major metabolic pathway for revefenacin was hydrolysis to the metabolite THRX-195518 (M2), and both revefenacin and THRX195518 underwent hepatic-biliary and fecal elimination after oral or intravenous administration with negligible renal excretion. Pharmacological evaluation of THRX-195518 indicated that it had a 10-fold lower binding affinity for the $M_{3}$ muscarinic receptor relative to revefenacin and that THRX-195518 has minimal contribution to systemic pharmacology after inhaled administration.

\section{Introduction}

Revefenacin (YUPELRI) is a novel once-daily, lung-selective, muscarinic antagonist developed and approved as a nebulized inhalation

This study was sponsored by Theravance Biopharma US, Inc. (South San Francisco, CA). This study and medical writing support were funded by Theravance Biopharma US, Inc. (South San Francisco, CA) and Mylan Inc. (Canonsburg, PA).

All authors had access to the data included in the manuscript. The data sets generated during the current study are not publicly available but can be requested from the corresponding author. D.L.B., S.Y., P.-J.C. are employees of Theravance Biopharma US, Inc. C.N.B. and S.S.H. are former employees of Theravance Biopharma US, Inc. M.T.B. is consultant for and received financial support from Theravance Biopharma US, Inc.

This study was partially presented at the Annual American Thoracic Society (ATS) International Conference, May 18-23, 2018, San Diego, CA.

https://doi.org/10.1124/dmd.120.000103.

S This article has supplemental material available at dmd.aspetjournals.org. solution for the maintenance treatment of patients with chronic obstructive pulmonary disease (COPD). As a potent and selective antagonist of human $M_{1}-M_{5}$ muscarinic receptors with kinetic selectivity for the $M_{3}$ over the $\mathrm{M}_{2}$ subtype (Hegde et al., 2018), revefenacin demonstrates bronchoselectivity with limited systemic effects after nebulized delivery. In phase 2 studies of patients with moderate to severe COPD, single or multiple doses of nebulized revefenacin, 22-700 $\mu \mathrm{g}$ once daily led to a rapid onset of effect and sustained bronchodilation for more than 24 hours with no clinically significant antimuscarinic adverse events (AEs), changes in laboratory variables, or prolongation of the QTc interval (Pudi et al., 2017; Quinn et al., 2018; Borin et al., 2020). In subsequent phase 3 studies, oncedaily revefenacin, 88 and $175 \mu \mathrm{g}$ (approved dose), was well tolerated and demonstrated clinically significant improvements from baseline in bronchodilation (measured using forced expiratory volume in 1 second) and in several respiratory health outcomes following up to 52 weeks of treatment (Donohue et al., 2019a,b; Ferguson et al., 2019).

In clinical pharmacokinetic (PK) studies evaluating single and repeated revefenacin dosing in patients with COPD, plasma concentrations of

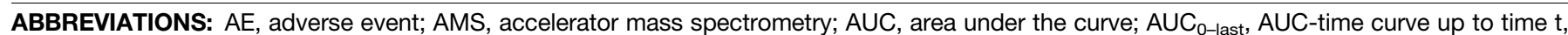
where $t$ is the last time point with concentrations above the lower limit of quantitation; BCRP, breast cancer resistance protein; $B: P$, fraction of total radioactivity in whole blood relative to plasma; COPD, chronic obstructive pulmonary disease; FRO, fractional receptor occupancy; hCES, human carboxylesterase; [ $\left.{ }^{3} \mathrm{H}\right] \mathrm{NMS}$, [N-methyl- $\left.{ }^{3} \mathrm{H}\right]$ scopolamine methyl chloride; HPLC, high-performance LC; LC, liquid chromatography; PK, pharmacokinetic; TEAE, treatment-emergent AE. 
revefenacin and its major metabolite THRX-195518 (M2) were low after inhaled administration and declined rapidly in a biexponential manner, resulting in limited plasma accumulation after repeated administration (Pudi et al., 2017; Quinn et al., 2018). Studies in patients with COPD also suggested THRX-195518 was a major metabolite because plasma exposure to the metabolite was approximately 4-fold higher than that of revefenacin (Quinn et al., 2018). No significant renal excretion of either compound was observed (Quinn et al., 2018).

This absorption, metabolism, and excretion study was conducted to evaluate the absolute bioavailability, mass balance, PK, and metabolic fate of revefenacin after intravenous and oral administration of ${ }^{14} \mathrm{C}$-labeled revefenacin $\left(\left[{ }^{14} \mathrm{C}\right]\right.$-revefenacin) in healthy subjects. Conducting radiolabeled absorption, distribution, metabolism, and excretion studies via the intended clinical route of administration is challenging for respiratory products that are administered via nebulization owing to numerous factors, including the inability to accurately quantify the delivered dose. Therefore, an intravenous microtracer was used in the current study as a surrogate for the portion of the inhaled revefenacin that reaches the systemic circulation via the lungs. An oral arm was also included in the study as a surrogate to understand the absorption and metabolism of any revefenacin that may be swallowed after inhaled administration. In vitro pharmacological characterization of the major revefenacin metabolite was also conducted, and its contribution to the overall systemic pharmacology relative to revefenacin was assessed with a receptor occupancy modeling approach.

\section{Materials and Methods}

Materials. $\left[N\right.$-methyl- $\left.{ }^{3} \mathrm{H}\right]$ scopolamine methyl chloride $\left(\left[{ }^{3} \mathrm{H}\right] \mathrm{NMS}\right.$ ) (specific activity $82 \mathrm{Ci} \mathrm{mmol}^{1}$ ) was obtained from GE Healthcare (Piscataway, NJ). Revefenacin, THRX-195518, THRX-609075, THRX-177860, THRX-193305, and THRX-697795 were prepared at Theravance Biopharma US, Inc. (South San Francisco, CA). $\left[{ }^{14} \mathrm{C}\right]$-revefenacin was synthesized at ViTrax (Placentia, CA).

Study Design and Treatments. This was an open-label, fixed-sequence, twoperiod study (NCT02772159) in nine healthy, nonsmoking males aged 19-55 years. For eligibility, the subjects had to have a body mass index of $18-32 \mathrm{~kg} / \mathrm{m}^{2}$, inclusive, and weigh at least $55 \mathrm{~kg}$.

Subjects received one ( $n=3$ receiving intravenous only; $n=3$ receiving oral only) or both ( $n=3$ receiving both intravenous and oral) of the following treatments in a fasted state with a $\geq 28$-day washout period between doses: a single $20-\mu \mathrm{g}$ intravenous infusion of approximately $1 \mu \mathrm{Ci}\left[{ }^{14} \mathrm{C}\right]$-revefenacin) over 30 minutes (period 1 ) and/or a single $200-\mu \mathrm{g}$ oral solution of approximately $10 \mu \mathrm{Ci}\left[{ }^{14} \mathrm{C}\right]-$ revefenacin (period 2).

$\left[{ }^{14} \mathrm{C}\right]$-revefenacin with a specific activity of approximately $50 \mu \mathrm{Ci} / \mathrm{mg}$ was supplied as a solution at a concentration of approximately $0.3 \mathrm{mCi} / \mathrm{ml}$ in ethanol. The sterile intravenous and oral solution drug products consisted of $\left[{ }^{14} \mathrm{C}\right]$ revefenacin in a 10-mM citrate buffer in normal saline at $\mathrm{pH}$ 5.0. No food was administered within 4 hours after dosing, and water was restricted for 1 hour before and after dosing except for water required for drug administration.

Documented approval was obtained from local institutional review boards for the protocol, and all materials were provided to subjects before the study started. The trial was conducted in accordance with the principles of the International Council on Harmonisation of Technical Requirements for Pharmaceuticals for Human Use guideline for good clinical practice (https://www.fda.gov/media/ 93884/download) and the code of ethics of the World Medical Association's Declaration of Helsinki (https://www.wma.net/policies-post/wma-declaration-ofhelsinki-ethical-principles-for-medical-research-involving-human-subjects/). All patients provided written informed consent. The trial was conducted at Celerion, Inc. (Lincoln, NE).

Assessments and Endpoints. Blood, plasma, urine, and feces were collected throughout periods 1 and 2 until the subject was discharged from the clinical research unit, which occurred if $\geq 90 \%$ of the administered radioactive dose had been recovered in excreta by day 8 or when the subject reached the maximum 15 day stay in the unit. For the intravenous administration arm, blood and plasma samples were collected predose and postdose at $0.25,0.5,0.6,0.75,1,2,3,4,5,6$, $8,12,24,36,48,72,96,120,144,168,192,216,240,264,288,312$, and
336 hours. For the oral administration arm, the collection time points were similar to the intravenous administration arm except that the 0.6 - and 0.75 -hour postdose time points were excluded. Urine was pooled for each collection interval. Urine samples were obtained predose and postdose at the following collection intervals: $0-4,4-8,8-12,12-24,24-48,48-72,72-96,96-120,120-144$, and 144-168 hours. If the clinical research unit discharge criteria were not met on day 8 , then urine samples were collected at the additional collection intervals, 168-192, 192-216, 216-240, 240-264, 264-288, 288-312, and 312-336 hours postdose, until the criteria were met. Fecal samples produced by individual subjects within a collection interval were processed separately and not combined before homogenization. Feces samples were obtained predose and postdose at the following collection intervals: 0-24, 24-48, 48-72, 72-96, 96-120, 120-144, and 144-168 hours. If the clinical research unit discharge criteria were not met on day 8, then feces were collected at the additional collection intervals, 168-192, 192-216, 216-240, 240-264, 264-288, 288-312, and 312-336 hours postdose, until the criteria were met.

Analytical Methods. Total ${ }^{14} \mathrm{C}$ content in plasma, whole blood, urine, and feces was assayed using liquid scintillation counting (feces and urine only) (Celerion) or accelerator mass spectrometry (AMS) (Xceleron, Inc., Germantown, MD). Metabolite profiles in pooled plasma, urine, and homogenized feces were determined using high-performance liquid chromatography (HPLC) with fraction collection by AMS. Liquid chromatography with tandem mass spectrometric detection $\left(\mathrm{Q}^{2}\right.$ Solutions, Ithaca, NY) was used to determine the concentrations of revefenacin and its metabolite THRX-195518 in plasma and urine. Liquid chromatography with tandem mass spectrometric bioanalysis methods are described in Supplemental Materials.

Accelerator Mass Spectrometry. All samples (blood, plasma, urine, and feces) were processed such that they would not saturate the AMS detector and were kept to less than $2.4 \mathrm{dpm}$ per AMS cathode. HPLC fractions or fraction pools were placed in tubes containing prebaked copper oxide. For samples containing little carbon (i.e., urine and HPLC fractions), sodium benzoate (equivalent to $\approx 1.7 \mathrm{mg}$ carbon) was added as a carbon carrier. Process standards (oxalic acid II and sodium benzoate) were placed in separate sample tubes containing prebaked copper oxide powder. All samples, standards, and controls were dried under vacuum. The glass sample tube containing the dried sample and copper oxide was placed into a larger quartz glass combustion tube with a drawn point, which was heat-sealed under vacuum and then heated at $900^{\circ} \mathrm{C}$ for 2 hours in a furnace. After combustion, the tube was allowed to cool to ambient temperature. $\mathrm{CO}_{2}$ was produced in the sealed tube by the oxidation of samples and controls during the heating process, and then $\mathrm{CO}_{2}$ was cryogenically transferred and sealed into a glass tube containing $\mathrm{TiH}_{2}$ and $\mathrm{Zn}$, with cobalt powder as the catalyst. Samples were heated for 4 hours at $500^{\circ} \mathrm{C}$ and then for 6 hours at $550^{\circ} \mathrm{C}$, reducing $\mathrm{CO}_{2}$ to solid carbon. Carbon was pressed into aluminum cathodes, which were placed in the ion source of a $5 \mathrm{MV}$ tandem pelletron. The ion source created a beam of negative ions by directing $\mathrm{a} \mathrm{Cs}^{+}$ion beam onto the graphite in each cathode in turn and sputtering the surface. The resultant secondary beam that was extracted from the ion source contained ${ }^{12} \mathrm{C}^{-},{ }^{13} \mathrm{C}^{-}$, and ${ }^{14} \mathrm{C}^{-}$ions. The ${ }^{14} \mathrm{C}$ content of each sample was calculated based on the ${ }^{14} \mathrm{C}:{ }^{12} \mathrm{C}$ ratio and the total carbon content. Carbon content was measured using a CHN analyzer (2400 Series 2; Perkin Elmer), or generic values were used. When appropriate, predose samples from the same subject were graphitized and analyzed to determine background ${ }^{14} \mathrm{C}:{ }^{12} \mathrm{C}$ ratios.

Metabolite Profiling in Plasma, Urine, and Feces. Plasma, urine, and fecal samples from the study period 1 and period 2 were assayed for total ${ }^{14} \mathrm{C}$ content using AMS at Xceleron. For metabolite profiling, plasma samples were pooled across individual subjects and time points (0-72 hours) according to the Hamilton area under the curve (AUC) pooling approach (Hamilton et al., 1981). Urine samples were pooled individually for the $0-4,4-8,8-12$, and 12-24 collection intervals and then for each 24-hour interval up to 168 hours and subsequently pooled across subjects. Fecal samples were pooled individually and then across subjects for the 0-216 hours interval. LC-UV (UV)/AMS analyses were conducted using HPLC/UV with offline ${ }^{14} \mathrm{C}$ detection by AMS at Xceleron. For the LC-UV/AMS analysis, cross-subjects pooled plasma $300 \mu l$ (period 1) and $500 \mu \mathrm{l}$ (period 2) were each protein precipitated separately with three volumes of acetonitrile:methanol $(1: 1, \mathrm{v} / \mathrm{v})$ containing $2 \mathrm{mM}$ ammonium acetate, vortex mixed, supernatant separated, and evaporated to dryness. The residue was then reconstituted into $200 \mu \mathrm{l}$ of ammonium acetate $(50 \mathrm{mM})$ in water. A portion of the reconstitution solution was then injected on the HPLC column, and fractions were collected for subsequent AMS analysis. 

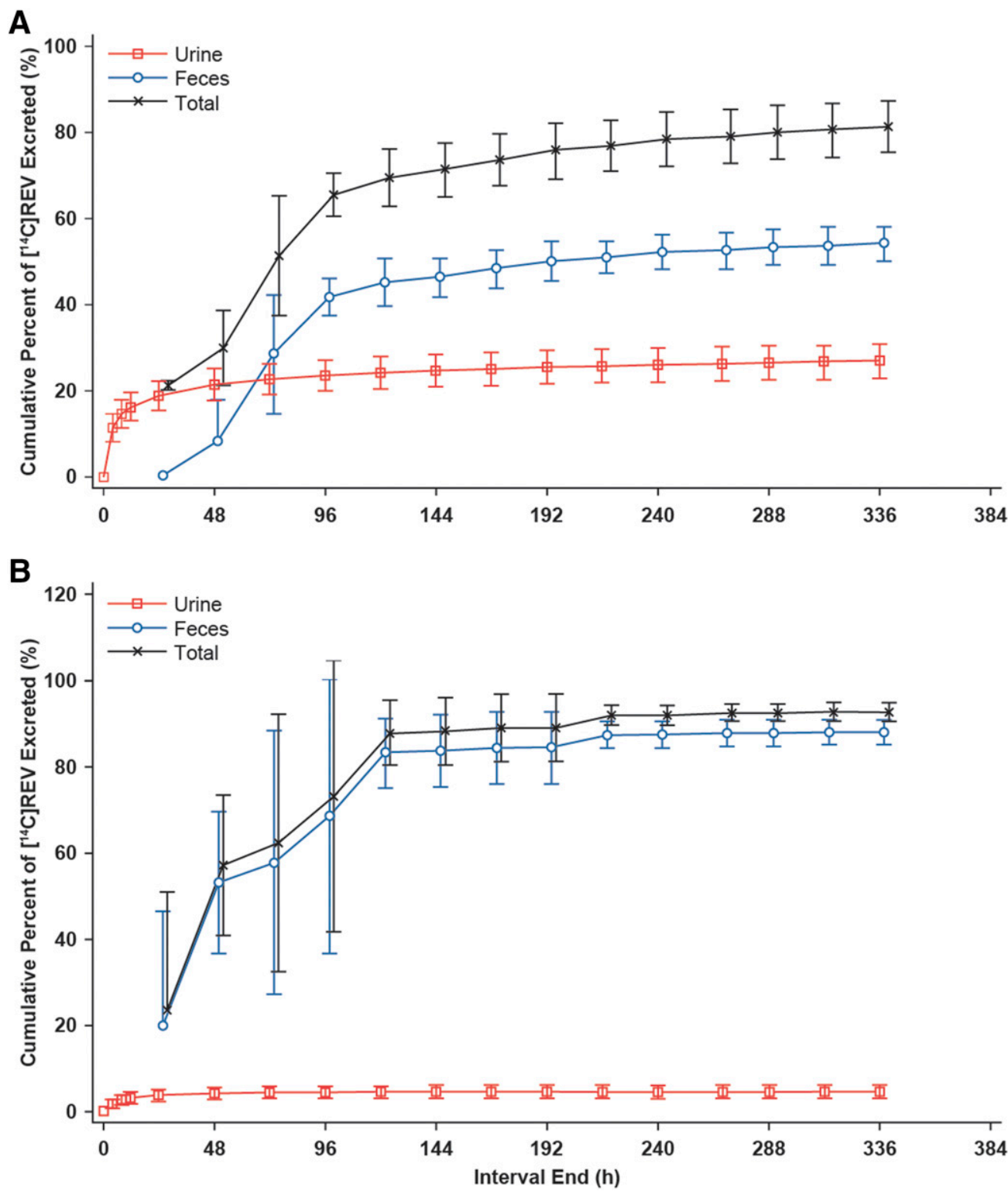

Fig. 1. Mean cumulative recovery of ${ }^{14} \mathrm{C}$ radioactivity in urine and feces after (A) a single intravenous dose of $20 \mu \mathrm{g}\left[{ }^{14} \mathrm{C}\right]$-revefenacin $(n=6)$ and (B) an oral dose of 200 $\mu \mathrm{g}\left[{ }^{14} \mathrm{C}\right]$-revefenacin $(n=6)$. h, hours; REV, revefenacin.

For urine samples of each study period 1 and 2, a 1/500th proportion was taken from each collection period from the 0-4 hours collection interval to the 144-168 hours collection intervals. After each individual subject pool was prepared, a cross-subject pool was prepared by taking a 1/10th portion (period 1 ) and $1 / 5$ th (period 2) of each subject pool and combining them together for each period. A portion of the reconstitution solution was used for AMS fractionation.

For fecal samples of each subject from study period 1 and 2, a 1/200th proportion of the feces homogenate sample aliquot was taken from each period to make an individual subject pool for 0-216 hours. After each subject pool was prepared, a cross-subject pool was made using one-fifth portion of each subject pool. Cross-subjects pooled fecal homogenate $300 \mathrm{mg}$ (period 1 and 2), each was extracted with three volumes of dimethylacetamide, vortex mixed and sonicated, and centrifuged, and then the supernatant was separated and diluted with ammonium acetate $(50 \mathrm{mM})$ in water. A portion of the diluted solution was used for AMS fractionation.

Plasma, urine, and feces metabolite profiling samples were spiked with reference standards [revefenacin; THRX-609075 (carbamate hydrolysis-revefenacin-M1); THRX-195518 (amide hydrolysis-revefenacin); THRX-177860 (N-dealkylation and oxidation-revefenacin-M8); THRX-193305 (hydrolysis and N-dealkylationrevefenacin-M9); THRX-697795 (N-dealkylation and reduction-revefenacin-M10)] and then fractionated by HPLC. Metabolite peaks were separated on a Phenomenex, Phenyl-Hexyl Luna column $(4.6 \times 250 \mathrm{~mm}, 5 \mu \mathrm{m})$ at a temperature set at $50^{\circ} \mathrm{C}$. Mobile phase A consisted of $50 \mathrm{mM}$ ammonium acetate in water, $\mathrm{pH} 7$, and mobile phase B consisted of acetonitrile:methanol (1:1, v/v). The flow rate was $1 \mathrm{ml} / \mathrm{min}$, and peaks were separated using a stepwise gradient from $5 \%$ to 95\% mobile phase B over 39 minutes $(5 \%-30 \%$ B from 0 to 8 minutes, $30 \%-50 \%$ B from 8 to 9 minutes, $50 \%-60 \%$ B from 9 to 31 minutes, $60 \%-95 \%$ B from 31 to 35 minutes, held at $95 \%$ B for 5 minutes, $95 \%-5 \%$ B from 39 to 40 minutes held at $5 \% \mathrm{~B}$ for 5 minutes before column re-equilibration at $5 \% \mathrm{~B}$ ). The eluent was collected as a series of fractions at 12-second intervals across each run. Fractions were analyzed either individually or pooled and then analyzed for ${ }^{14} \mathrm{C}$ content by AMS as described earlier. UV chromatograms with the spiked reference standards were overlaid with the radio-chromatograms based on the AMS detection of fractions and fraction pools to confirm the identity of revefenacin and its metabolites in each matrix.

Metabolite Identification. Retention times of the metabolite peaks from plasma, urine, and fecal metabolite profiling samples were compared with the metabolites observed in a $\operatorname{dog}{ }^{14} \mathrm{C}$ absorption, distribution, metabolism, and excretion study (data on file). The structures of the metabolites were determined from the dog study using HPLC-UV-mass spectrometry, 
A
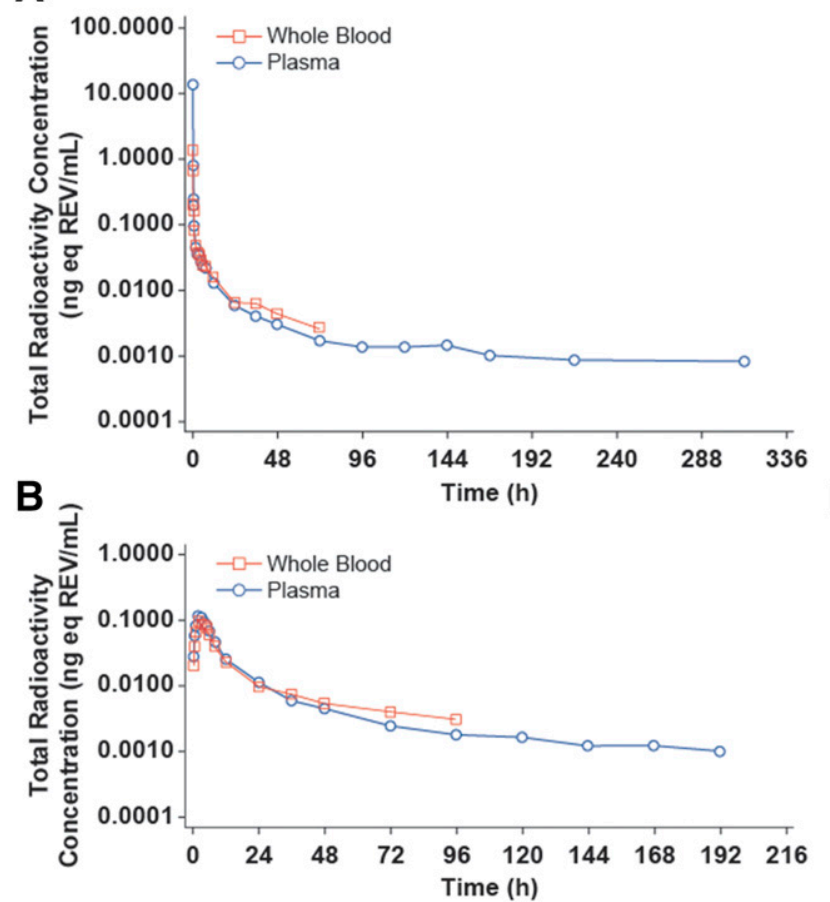

C
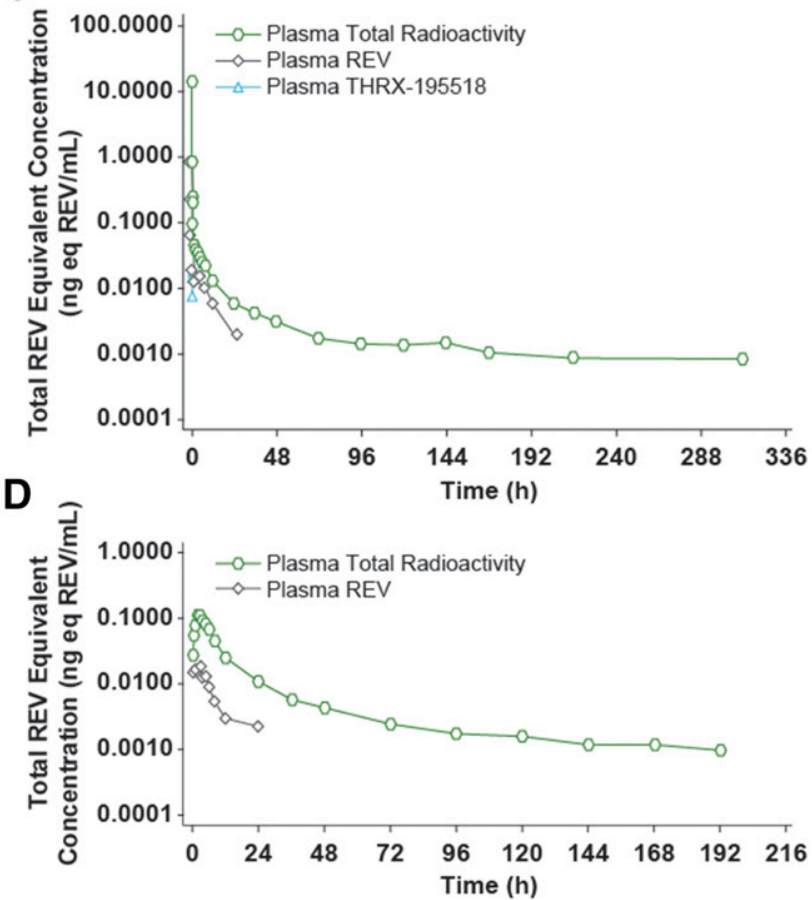

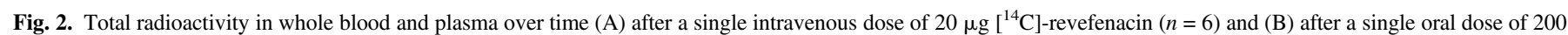

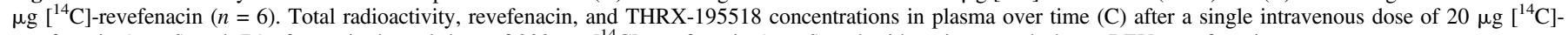
revefenacin $(n=6)$ and (D) after a single oral dose of $200 \mu \mathrm{g}\left[{ }^{14} \mathrm{C}\right]$-revefenacin $(n=6)$ and arithmetic mean. h, hour; REV, revefenacin.

Thermo Finnigan LTQ-Orbitrap (ThermoFisher Corporation) in a full scan mode $(\mathrm{m} / \mathrm{z}, 150-900)$ at a resolution setting of 30,000. Capillary temperature was set at $275^{\circ} \mathrm{C}$, and the source potential was $5000 \mathrm{~V}$. Other potentials were optimized based upon ionization and fragmentation of the parent compound. UV absorption spectra were obtained by an in-line photodiode array detector. Metabolite peaks were separated on a Phenomenex, Phenyl-Hexyl Luna column $(4.6 \times 250 \mathrm{~mm}, 5 \mu \mathrm{m})$ at a temperature set at $50^{\circ} \mathrm{C}$. Mobile phase A consisted of $50 \mathrm{mM}$ ammonium acetate in water, $\mathrm{pH} 7$, and mobile phase $\mathrm{B}$ consisted of acetonitrile:methanol (1:1, $\mathrm{v} / \mathrm{v})$. The flow rate was $1 \mathrm{ml} / \mathrm{min}$, and peaks were separated using a stepwise gradient from $5 \%$ to $95 \%$ mobile phase B over 39 minutes (5\%-30\% B from 0 to 8 minutes, $30 \%-50 \%$ B from 8 to 9 minutes, $50 \%-60 \%$ B from 9 to 31 minutes, $60 \%-95 \%$ B from 31 to 35 minutes, held at $95 \%$ B for 5 minutes, $95 \%-5 \%$ B from 39 to 40 minutes held at $5 \%$ B for 5 minutes before column re-equilibration at $5 \%$ B). Proposed structures were compared with available authentic standards THRX609075, THRX-195518, THRX-177860, THRX-193305, and THRX697795 .

Pharmacokinetic Evaluations. Noncompartmental PK parameters were calculated from the total radioactivity of $\left[{ }^{14} \mathrm{C}\right]$-revefenacin-derived concentration equivalent-time data in whole blood and plasma as well as plasma revefenacin and THRX-195518 concentration-time data (Phoenix WinNonlin Version 6.3; Certara USA, Inc., Princeton, NJ). Urinary excretion and renal clearance were estimated from individual total radioactivity concentration equivalents in urine or urine revefenacin and THRX-195518 concentrations and volumes using SAS, Version 9.3 (SAS, Institute Inc., Cary, NC). Fecal excretion was estimated from individual total radioactivity concentration equivalents in feces and fecal homogenate weights. Mass balance was calculated individually as the sum of the percent of total radioactivity recovered in urine and feces. The absolute bioavailability of revefenacin was assessed using plasma concentration data from subjects who completed both dosing periods.

Radioligand Binding Studies at $\mathbf{h M}_{1}, \mathbf{h M}_{2}, \mathbf{h M _ { 3 }}, \mathbf{h M _ { 4 }}$, and $\mathbf{h M}$. Studies were conducted using Chinese hamster ovary-K1 cell membrane fractions stably expressing human recombinant $\mathrm{M}_{1}, \mathrm{M}_{2}, \mathrm{M}_{3}, \mathrm{M}_{4}$, or $\mathrm{M}_{5}$ muscarinic acetylcholine receptors. Assays were conducted with $1 \mathrm{nM}\left[{ }^{3} \mathrm{H}\right] \mathrm{NMS}$ in a 10-mM HEPES buffer containing $100 \mathrm{mM} \mathrm{NaCl}, 10 \mathrm{mM} \mathrm{MgCl}_{2}$, and $0.025 \%$ bovine serum albumin, $\mathrm{pH} 7.4$, at $37^{\circ} \mathrm{C}$. Nonspecific binding was defined in the presence of $10 \mu \mathrm{M}$ atropine.

Revefenacin and THRX-195518 Receptor Occupancy. Receptor occupancy at the M3 receptor for revefenacin and THRX-195518 after nebulized inhalation dosing was calculated using a fractional receptor occupancy (FRO) model. The FRO for revefenacin and THRX-195518 was calculated using the unbound plasma concentration (in nanomolar) of revefenacin and THRX-195518 at each time point determined in a multiple-dose clinical trial at steady state (Quinn et al., 2018). FRO for revefenacin and THRX-195518 was calculated using the equations:

$$
\begin{aligned}
\text { FRO } & =\frac{\text { unbound revefenacin }(\mathrm{nM})}{\left[\text { unbound revefenacin }+\left(\mathrm{K}_{\mathrm{i}_{\text {revefenacin }}} \times\left(1+\text { unbound THRX }-195518 / \mathrm{K}_{\mathrm{i}_{\text {THRX-195518 }}}\right)\right]\right.} \\
\mathrm{FRO} & =\frac{\text { unbound THRX }-195518(\mathrm{nM})}{\left[\text { unbound THRX }-195518+\left(\mathrm{K}_{\mathrm{i} \text { THRX }-195518} \times\left(1+\text { unbound revefenacin } / \mathrm{K}_{\mathrm{i}_{\text {reverefenacin }}}\right)\right]\right.}
\end{aligned}
$$

Total combined $\mathrm{M}_{3}$ receptor occupancy for the contribution of revefenacin and THRX-195518 was then determined using the sum of the respective fractional receptor occupancies.

Safety Assessments. Safety was evaluated by physical examination, vital sign measurement, 12-lead electrocardiogram, clinical laboratory tests, treatmentemergent adverse events (TEAEs), and concomitant medication monitoring.

\section{Results}

Study Participants. A total of nine male subjects were enrolled in the study: Three received only the $20-\mu \mathrm{g}$ intravenous infusion, three received only the $200-\mu \mathrm{g}$ oral solution, and three received both treatments. All subjects completed dosing and the required assessments. Demographic and baseline characteristics were similar between treatments [mean age 31.8 years, range $22.0-46.0$ years; $n=6(66.7 \%)$ White, $n=3(33.3 \%)$ Black or African American; mean body weight $80.0 \mathrm{~kg} \pm 15.9$ S.D.; mean body mass index $25.3 \pm 4.08$ (S.D.)].

Mass Balance and Excretion. A mean (S.D.) of 81.4 (6.0)\% of drugrelated radioactive material was recovered after intravenous administration of revefenacin, with 54.4 (3.8)\% excreted in feces and 27.1 
(4.0)\% excreted in urine. After oral administration, 92.7 (2.2)\% of the total dose was recovered, with 88.0 (2.9)\% excreted in feces and 4.7 (1.5)\% excreted in urine. Figure 1, A and B show the mean cumulative percentage of radioactivity excreted in urine and feces and the combined total excretion over time.

Total Radioactivity in Whole Blood and Plasma. After intravenous and oral administration of $\left[{ }^{14} \mathrm{C}\right]$-revefenacin, mean total radioactivity plots showed similar profiles for whole blood and plasma (Fig. 2, A and B). Intravenous administration led to a multiphasic, relatively parallel postpeak decline in mean total blood and plasma concentration equivalents up to 72 hours postdose. Total radioactivity remained measurable in the plasma until 312 hours after infusion; however, blood concentrations were unable to be reliably quantified at these later time points. Maximal blood and plasma concentrations were achieved by the end of the intravenous infusion (i.e., after 30 minutes). Maximal mean blood and plasma concentrations were achieved 2 hours after oral dosing.

Total Radioactivity, Revefenacin, and THRX-195518 Plasma Concentration-Time Profiles. After intravenous administration, maximal mean plasma concentrations of total radioactivity and revefenacin were achieved 30 minutes after initiation of the infusion (Fig. 2C). There was a postpeak multiphasic, parallel decline in plasma concentrations up to 36 hours after infusion. After 48 hours, almost all radioactive revefenacin was undetectable. Plasma THRX-195518 was detectable in most subjects 45 minutes after starting the infusion and remained measurable at 2 hours.

After oral dosing, maximal mean plasma concentrations were achieved after 2 hours for total radioactivity and 3 hours for revefenacin (Fig. 2D). Subsequent parallel declines in mean plasma concentrations were observed for 24 hours after dosing prior to plasma revefenacin concentration equivalents becoming undetectable. Plasma THRX195518 was virtually undetectable throughout the sampling window.

Pharmacokinetics of Total Radioactivity in Whole Blood and Plasma. A summary of PK parameters of total radioactivity in whole blood and plasma is shown in Table 1. After intravenous administration, mean AUC from time zero to time $t$, in which $t$ is the last time point with concentrations above the lower limit of quantitation $\left(\mathrm{AUC}_{0-\text { last }}\right)$, and
$\mathrm{C}_{\max }$ for whole blood and plasma total radioactivity were skewed because of a single subject with outlying values. Median values were therefore used for the assessment of intravenous PK parameters. $\operatorname{AUC}_{0-\text { last }}\left(1.09\right.$ and $1.28 \mathrm{ng} \mathrm{eq} * \mathrm{~h} / \mathrm{ml}$, respectively) and $\mathrm{C}_{\max }(0.70$ and $0.88 \mathrm{ng}$ eq/ml, respectively) were similar in whole blood and plasma, respectively. The fraction of total radioactivity in whole blood relative to plasma (B:P) AUC ratio was 0.95 , and $\mathrm{B}: \mathrm{P} \mathrm{C}_{\max }$ ratio was 0.73 .

After oral dosing, total radioactivity mean (Table 1 ) and median total radioactivity $\mathrm{AUC}_{0-\text { last }}(1.26$ and $1.64 \mathrm{ng} \mathrm{eq} * \mathrm{~h} / \mathrm{ml})$, AUC from time zero to infinity $(1.01$ and $1.43 \mathrm{ng} \mathrm{eq} * \mathrm{~h} / \mathrm{ml})$, and $C_{\max }(0.11$ and $0.14 \mathrm{ng} \mathrm{eq} / \mathrm{ml})$ were similar in whole blood and plasma, respectively. Mean B:P AUC and $\mathrm{C}_{\max }$ ratios were approximately 0.9 , indicating equal partitioning between red blood cells and plasma.

Pharmacokinetics of Revefenacin and THRX-195518 in Plasma. A summary of PK parameters of revefenacin in plasma is shown in Supplemental Table 1. After intravenous administration, AUC and $\mathrm{C}_{\max }$ ratios of revefenacin to total radioactivity in plasma (mean [S.D.]: 0.56 [0.26] and 0.73 [0.35], respectively) showed that the majority of radioactivity was associated with intact revefenacin (Fig. 2C). By contrast, ratios of 0.16 [0.03] and 0.20 [0.04], respectively, after oral administration, indicated that total radioactivity was primarily associated with revefenacin metabolites rather than the parent revefenacin (Fig. 2D). Mean [S.D.] absolute bioavailability of oral revefenacin was low (2.8 [1.2]\%) based on within-subject comparison $(n=3)$.

Plasma concentrations of THRX-195518 were generally very low $(<0.02 \mathrm{ng} / \mathrm{ml})$, especially after oral administration of revefenacin, when PK parameters could not be determined (Fig. 2C). After intravenous administration, mean [S.D.] $\mathrm{AUC}_{0-\text { last }}$ and $\mathrm{C}_{\max } \mathrm{THRX}-195518$ to revefenacin ratios were 0.08 [0.06] and 0.03 [0.01], respectively.

Metabolite Profiling in Plasma. Unchanged revefenacin was identified as the primary species circulating in human plasma after intravenous and oral administration. The percentages of unchanged revefenacin and revefenacin metabolites identified in pooled plasma after intravenous and oral administration are shown in Table 2. The radio-chromatogram based on AMS detection and overlaid with the UV chromatogram containing known revefenacin and metabolite reference

TABLE 1

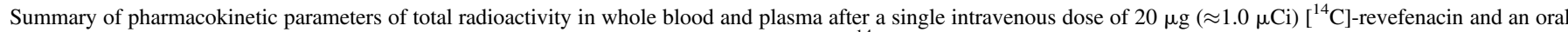
dose of $200 \mu \mathrm{g}(\approx 10.0 \mu \mathrm{Ci})\left[{ }^{14} \mathrm{C}\right]$-revefenacin

\begin{tabular}{|c|c|c|c|c|c|c|c|c|c|c|c|c|}
\hline \multirow[b]{3}{*}{ Parameter } & \multicolumn{6}{|c|}{ Whole Blood } & \multicolumn{6}{|c|}{ Plasma } \\
\hline & \multicolumn{3}{|c|}{ Intravenous Dose } & \multicolumn{3}{|c|}{ Oral Dose } & \multicolumn{3}{|c|}{ Intravenous Dose } & \multicolumn{3}{|c|}{ Oral Dose } \\
\hline & Mean (S.D.) & Median (min, max) & $n$ & Mean (S.D.) & Median (min, max) & $n$ & Mean (S.D.) & $\begin{array}{l}\text { Median (min, } \\
\max \text { ) }\end{array}$ & $n$ & Mean (S.D.) & Median (min, max) & $n$ \\
\hline $\begin{array}{c}\mathrm{AUC}_{0-\text { last }} \text { (ng } \\
\left.\mathrm{eq}^{a} \mathrm{~h} / \mathrm{ml}\right)\end{array}$ & $1.32(0.79)$ & $1.09(0.69,2.86)$ & 6 & $1.22(0.72)$ & $1.26(0.24,2.18)$ & 6 & $5.05(9.33)$ & $\begin{array}{c}1.28(1.04 \\
24.1)\end{array}$ & 6 & $1.41(0.70)$ & $1.64(0.36,2.07)$ & 6 \\
\hline $\begin{array}{r}\mathrm{AUC}_{\text {inf }}(\mathrm{ng} \\
\left.\mathrm{eq}^{a} \mathrm{~h} / \mathrm{ml}\right)\end{array}$ & $1.11(0.28)$ & $1.18(0.77,1.48)$ & 5 & $1.14(0.66)$ & $1.01(0.30,1.81)$ & 5 & $1.23,1.71^{b}$ & - & 2 & $1.39(0.77)$ & $1.43(0.39,2.16)$ & 5 \\
\hline $\begin{array}{l}\mathrm{C}_{\max } \text { (ng eq/ } \\
\mathrm{ml} \text { ) }\end{array}$ & $1.50(2.13)$ & $0.70(0.50,5.84)$ & 6 & $0.11(0.06)$ & $0.110(0.03,0.17)$ & 6 & $14.10(32.60)$ & $\begin{array}{c}0.88(0.69 \\
80.60)\end{array}$ & 6 & $0.13(0.07)$ & $0.14(0.03,0.20)$ & 6 \\
\hline $\mathrm{T}_{\max }(\mathrm{h})$ & $0.45(0.11)$ & $0.52(0.25,0.52)$ & 6 & $2.84(1.16)$ & $2.52(2.00,5.00)$ & 6 & $0.36(0.13)$ & $\begin{array}{c}0.32(0.25 \\
0.52)\end{array}$ & 6 & $2.84(1.16)$ & $2.52(2.00,5.00)$ & 6 \\
\hline$t_{1 / 2}(\mathrm{~h})$ & $\begin{array}{l}25.29 \\
(8.33)\end{array}$ & $\begin{array}{c}25.82(12.63 \\
35.40)\end{array}$ & 5 & $\begin{array}{c}25.59 \\
(20.31)\end{array}$ & $\begin{array}{c}15.31(10.34 \\
60.15)\end{array}$ & 5 & $\begin{array}{c}70.85 \\
166.78^{b}\end{array}$ & - & 2 & $\begin{array}{c}56.65 \\
(47.44)\end{array}$ & $\begin{array}{c}44.26(20.39 \\
137.77)\end{array}$ & 5 \\
\hline $\begin{array}{c}\mathrm{B}: \mathrm{P} \text { AUC } \\
\text { ratio }^{c}\end{array}$ & - & - & - & - & - & - & $0.85(0.36)$ & $\begin{array}{c}0.95(0.12 \\
1.09)\end{array}$ & 6 & $0.93(0.11)$ & $0.92(0.81,1.13)$ & 6 \\
\hline $\begin{array}{l}\mathrm{B}: \mathrm{P} \mathrm{C}_{\max } \\
\text { ratio }^{d}\end{array}$ & - & - & - & - & - & - & $0.65(0.29)$ & $\begin{array}{c}0.73(0.07 \\
0.83)\end{array}$ & 6 & $0.85(0.08)$ & $0.86(0.72,0.95)$ & 6 \\
\hline
\end{tabular}

$\mathrm{AUC}_{\mathrm{inf}}$, AUC-time curve from time zero to infinity; max, maximum; min, minimum; ng eq, ng equivalent revefenacin; $\mathrm{T}_{\max }$, time to attain $\mathrm{C}_{\max }$

${ }^{a} \mathrm{~T}_{\max }$ is presented as median (minimum, maximum)

${ }^{b}$ Individual values reported since $n=2$.

${ }^{c} \mathrm{~B}: \mathrm{P}$ AUC ratio, fraction of the AUC of total radioactivity in whole blood relative to the AUC of total radioactivity in plasma.

${ }^{d} \mathrm{~B}: \mathrm{P} \mathrm{C}_{\max }$ ratio, fraction of the $\mathrm{C}_{\max }$ of total radioactivity in whole blood relative to the $\mathrm{C}_{\max }$ of total radioactivity in plasma. 
TABLE 2

Percentage of revefenacin and its metabolites identified in pooled plasma after a single intravenous dose of $20 \mu \mathrm{g}\left[{ }^{14} \mathrm{C}\right]$-revefenacin $(n=6)$ and an oral dose of 200 $\mu \mathrm{g}\left[{ }^{14} \mathrm{C}\right]$-revefenacin $(n=6)$

$\left[{ }^{14} \mathrm{C}\right]$-revefenacin, $\left[{ }^{14} \mathrm{C}\right]$-labeled revefenacin.

\begin{tabular}{lcc}
\hline & $\begin{array}{c}\text { Circulating Radioactivity } \\
(\%)\end{array}$ & $\begin{array}{c}\text { Circulating Radioactivity } \\
(\%) \text { Oral }\end{array}$ \\
\hline Revefenacin & 52.1 & 13.1 \\
THRX-195518 (M2) & 14.3 & 12.5 \\
THRX-697795 (M10) & 4.79 & 12.5 \\
THRX-193305 (M9) & 2.81 & 2.93 \\
THRX-609075 (M1) & 1.66 & 3.63 \\
THRX-177860 (M8) & 1.58 & 3.69 \\
\hline
\end{tabular}

standards supporting the structural assignment is shown in Supplemental Fig. 1. Intact revefenacin accounted for approximately $52.1 \%$ and $13.1 \%$ of the total circulating radioactivity after an intravenous and oral administration, respectively. Two main circulating metabolites were observed in plasma. After an intravenous dose, the hydrolysis product THRX-195518 (M2) was the primary metabolite and observed at $14.3 \%$ of total circulating radioactivity. After an oral dose, both THRX-195518 (M2) and THRX-697795 (M10; generated after amide hydrolysis and $\mathrm{N}$-dealkylation of the parent compound) were observed at $12.5 \%$ and $12.5 \%$ of total radioactivity, respectively. Other minor metabolites identified in human plasma included THRX-177860 (M8) and THRX-193305 (M9).

Metabolite Profiling in Feces and Urine. Metabolite profiling was conducted in human excreta (pooled feces and urine) after single intravenous or oral administration. The percentage of the dose recovered for revefenacin and metabolites excreted in feces and urine is shown in Table 3. The radio-chromatograms based on AMS detection and overlaid UV chromatograms support the structural assignment and are shown in Supplemental Figs. 2-4. The majority of the administered dose was excreted in feces after intravenous and oral administration. After intravenous and oral administration, the primary metabolite identified in feces was hydrolysis to THRX-195518 (M2), with $18.8 \%$ and $9.4 \%$ of the dose recovered. Unchanged revefenacin was also significant in feces, with $15.4 \%$ and $66.8 \%$ of the dose recovered. The primary species identified in human urine was unchanged revefenacin, with all metabolites present at minor amounts $(<5 \%$ of the dose).

In summary, the major metabolic pathway after intravenous or oral administration was hydrolysis of revefenacin to THRX-195518 (Fig. 3). Additional metabolic pathways included conversion to THRX-609075 (M1) by hydrolysis, formation of THRX-177860 (M8) and THRX697795 (M10) via N-dealkylation and their subsequent oxidation and reduction, respectively, and formation of THRX-193305 (M9) after N-dealkylation of THRX-195518 (M2).

In Vitro Pharmacology of THRX-195518. Results of radioligand binding experiments are summarized in Table 4 . Affinity measurements for revefenacin were previously published (Hegde et al., 2018). THRX195518 had a moderate binding affinity for the five human muscarinic acetylcholine receptors $\left(\mathrm{hM}_{1-5}\right)$. Measured THRX-195518 binding affinities at the five muscarinic receptors in radioligand displacement experiments with $\left[{ }^{3} \mathrm{H}\right] \mathrm{NMS}$ were $\mathrm{hM}_{1} \mathrm{~K}_{\mathrm{I}}=1.2 \mathrm{nM} ; \mathrm{hM}_{2} \mathrm{~K}_{\mathrm{I}}=2.0 \mathrm{nM}$; $\mathrm{hM}_{3} \mathrm{~K}_{\mathrm{I}}=1.8 \mathrm{nM} ; \mathrm{hM}_{4} \mathrm{~K}_{\mathrm{I}}=1.6 \mathrm{nM}$; and $\mathrm{hM}_{5} \mathrm{~K}_{\mathrm{I}}=17 \mathrm{nM}$. The binding affinity for THRX-195518 was approximately 10-fold lower than for revefenacin at the $\mathrm{hM} 3$ receptor.

Contribution of THRX-195518 to Systemic Pharmacology. The time course of the combined [revefenacin + THRX-195518] and THRX195518 contribution to the mean $\mathrm{M}_{3}$ receptor occupancy at steady state at the therapeutic dose of revefenacin $175 \mu \mathrm{g}$ is depicted in Fig. 4. Combined $\mathrm{M}_{3}$ receptor occupancies at the therapeutic dose of $175 \mu \mathrm{g}$ were low and did not exceed $30 \%$ at any time point at steady state. The metabolite (THRX-195518) contribution to $\mathrm{M}_{3}$ occupancy at the proposed therapeutic dose was negligible and did not exceed $10 \%$ at any time point postdose.

Safety. Two subjects receiving $\left[{ }^{14} \mathrm{C}\right]$-revefenacin $20 \mu \mathrm{g}$ intravenously and one receiving $\left[{ }^{14} \mathrm{C}\right]$-revefenacin $200 \mu \mathrm{g}$ orally reported mild TEAEs. Single TEAEs of abdominal discomfort, nausea, and headache reported by one subject were considered possibly/probably related to study drug (20- $\mu \mathrm{g}$ intravenous infusion). No serious AEs, clinically significant abnormalities, changes in routine clinical laboratory test results, or clinically significant changes in the electrocardiogram evaluations compared with baseline values were reported.

\section{Discussion}

In this open-label absorption, metabolism, and excretion study, nine healthy adult male subjects received a single intravenous dose of $20 \mu \mathrm{g}$ $(\approx 1.0 \mu \mathrm{Ci})\left[{ }^{14} \mathrm{C}\right]$-revefenacin and/or an oral dose of $200 \mu \mathrm{g}(\approx 10.0$ $\mu \mathrm{Ci})\left[{ }^{14} \mathrm{C}\right]$-revefenacin) while fasting. Approximately $81 \%$ and $93 \%$ of the total intravenous and oral doses were recovered, respectively, of which fecal excretion accounted for 54\% and $88 \%$, respectively, and renal excretion accounted for $\leq 6 \%$. Total radioactivity recovery in this study was acceptable $(>80 \%)$ based upon historical analysis of radiolabeled mass balance studies and conventionally acceptable targets for radioactive recovery (Roffey et al., 2007). The low absolute oral bioavailability $(<3 \%)$ of revefenacin after oral administration and high recovery of unchanged revefenacin in feces after oral administration are consistent with poor oral absorption and suggest that the swallowed portion of the dose after inhaled administration will not contribute significantly to systemic drug levels. Estimation of the fraction absorbed from radiolabeled intravenous and oral dosing can be accomplished by comparison of the amount of total radioactivity excreted in urine after oral and intravenous administration and suggests that the fraction absorbed of revefenacin is less than $20 \%$. The poor oral absorption observed for revefenacin also likely explains the higher recovery of total radioactivity after oral (93\%) versus intravenous $(81 \%)$ dosing.

TABLE 3

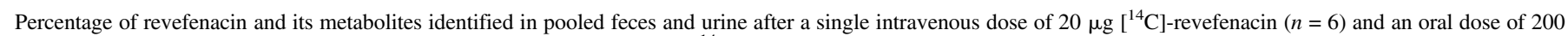
$\mu \mathrm{g}\left[{ }^{14} \mathrm{C}\right]$-revefenacin $(n=6)$

$\left[{ }^{14} \mathrm{C}\right]$-revefenacin, $\left[{ }^{14} \mathrm{C}\right]$-labeled revefenacin.

\begin{tabular}{|c|c|c|c|c|}
\hline & \multicolumn{2}{|c|}{ Administered Dose (\%) Intravenous } & \multicolumn{2}{|c|}{ Administered Dose (\%) Oral } \\
\hline & Feces & Urine & Feces & Urine \\
\hline Revefenacin & 15.4 & 11.8 & 66.8 & 0.32 \\
\hline THRX-195518 (M2) & 18.8 & 2.19 & 9.38 & 0.18 \\
\hline THRX-697795 (M10) & 1.03 & $<1$ & 1.36 & 0.98 \\
\hline THRX-193305 (M9) & $<0.10$ & $<1$ & 0.38 & 0.69 \\
\hline THRX-609075 (M1) & 0.98 & 1.76 & 0.31 & 0.19 \\
\hline THRX-177860 (M8) & $<0.10$ & 2.84 & $<0.10$ & 0.73 \\
\hline
\end{tabular}




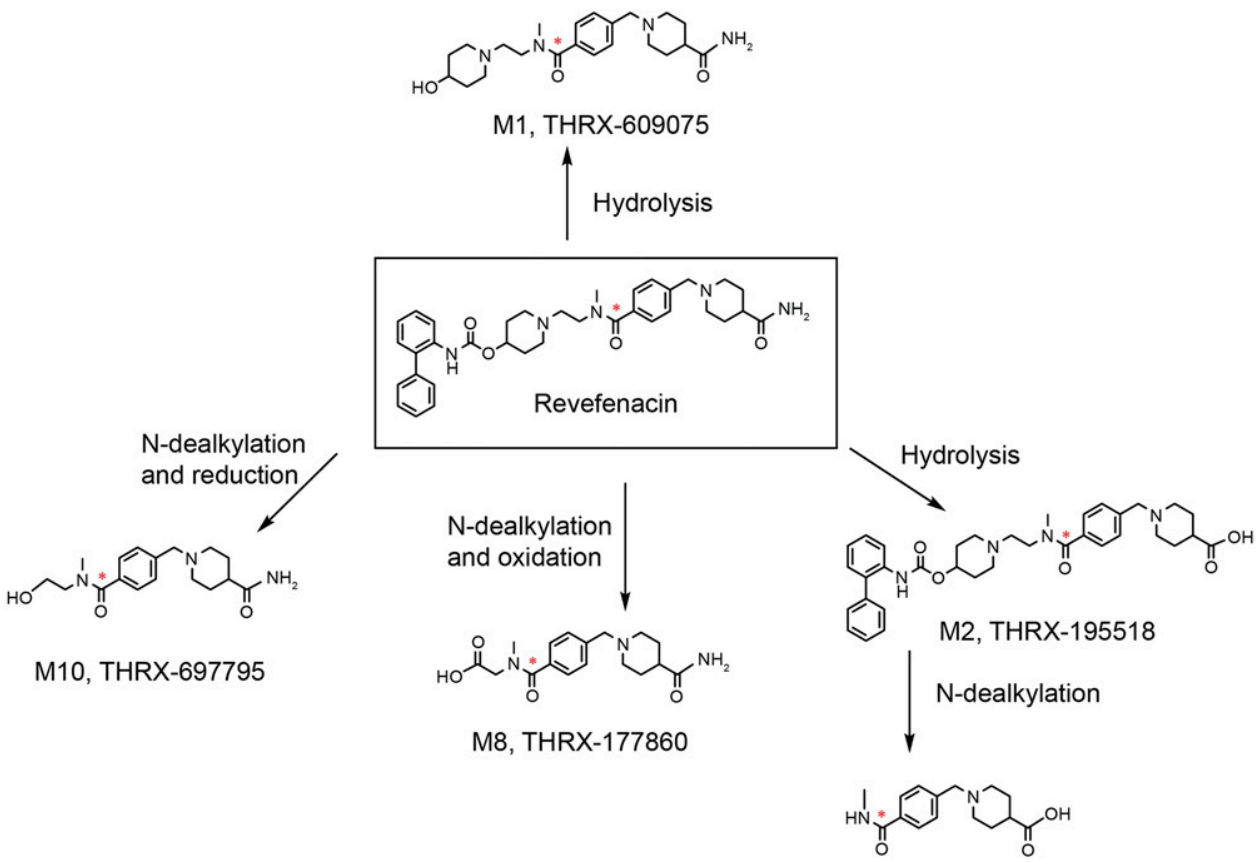

Fig. 3. Metabolic pathways for revefenacin in humans.

* Radiolabel

M9, THRX-193305

The relatively lower recovery of total radioactivity after administration of microtracer doses has been previously observed for other inhaled therapeutics and may reflect slow tissue redistribution, longer elimination, and/or logistical challenges with complete recovery of the dose after microtracer administration and AMS analysis (Harrell et al., 2013, 2019).

The poor oral absorption of revefenacin demonstrated in this study may be partially attributed to the susceptibility of revefenacin to efflux by both P-glycoprotein (P-gp) and breast cancer resistance protein (BCRP) (https://www.accessdata.fda.gov/drugsatfda_docs/nda/2018/ 210598Orig1s000ClinPharmR.pdf). Given the low inhaled dose of revefenacin $(175 \mu \mathrm{g})$, it is unlikely that the portion of that dose that ends up being swallowed would saturate efflux transport in the intestine, and thus P-gp and BCRP may be an important mechanism limiting absorption of revefenacin. Expression of both P-gp and BCRP transporters has also been reported in human lung tissue and human lungderived cells (Berg et al., 2014, 2018; Fallon et al., 2018). Although the relative abundance of these efflux transporters in the lung is believed to be lower than that observed in other tissues, including the intestine, their functional role with respect to lung disposition remains to be fully elucidated. Studies in rat and multidrug resistance $1 \mathrm{a} / 1 \mathrm{~b}$ knockout mouse isolated lung models have suggested that a prototypical P-gp substrate (rhodamine-123) exhibits greater lung absorption under conditions of transporter knockout relative to wild-type controls, suggesting that P-gp may play some role in lung disposition (Al-Jayyoussi et al., 2013). The relative impact of P-gp or BCRP on the lung disposition and efficacy of revefenacin remains to be investigated.

The excretion profile of revefenacin was consistent with elimination via the hepatic-biliary and fecal route. Revefenacin and the primary metabolite THRX-195518 were subject to low recovery in urine after intravenous and oral administration, suggesting that renal clearance of the drug is a minor elimination route. This finding is consistent with the excretion profile from prior $\mathrm{PK}$ studies of inhaled revefenacin in patients with moderate to severe COPD, in which no significant renal excretion was observed (Quinn et al., 2018).

Comparison of the whole blood and plasma total radioactivity concentration equivalents showed that $\left[{ }^{14} \mathrm{C}\right]$-revefenacin-related radioactivity after intravenous or oral administration was predominantly associated with plasma during the early absorption phase and then gradually shifted toward red blood cells. The total radioactivity B:P AUC ratio after intravenous or oral administration averaged $>0.9$, suggesting that $\left[{ }^{14} \mathrm{C}\right]$-revefenacin-related total radioactivity was partitioned almost equally between red blood cells and plasma.

After intravenous administration, most plasma radioactivity was associated with intact revefenacin with a smaller contribution from metabolites (plasma revefenacin to total radioactivity mean AUC and $\mathrm{C}_{\max }$ ratios of approximately 0.6 and 0.7 , respectively). After oral administration, plasma revefenacin to plasma total radioactivity mean AUC and $\mathrm{C}_{\max }$ ratios were approximately 0.2 , which is suggestive of extensive first-pass metabolism.

TABLE 4

Binding affinities of revefenacin and THRX-195518 at $\mathrm{M}_{1}, \mathrm{M}_{2}, \mathrm{M}_{3}, \mathrm{M}_{4}$, and $\mathrm{M}_{5} \mathrm{mAChRs}$

Binding affinities for revefenacin and THRX-195518 at CHO-K1 cell membranes expressing $\mathrm{M}_{1}, \mathrm{M}_{2}, \mathrm{M}_{3}, \mathrm{M}_{4}$, and $\mathrm{M}_{5}$ mAChRs were determined using [ $\mathrm{H}$ ] NMS inhibition radioligand binding assays. Data are expressed as mean \pm S.D.; $\mathrm{n}=$ at least 12 .

\begin{tabular}{|c|c|c|c|c|c|}
\hline & $\mathrm{hM}_{1}$ & $\mathrm{hM}_{2}$ & $\mathrm{hM}_{3}$ & $\mathrm{hM}_{4}$ & $\mathrm{hM}_{5}$ \\
\hline Revefenacin $^{a}, \mathrm{~K}_{\mathrm{i}}, \mathrm{nM} \pm$ S.D. & $0.4 \pm 0.03$ & $0.3 \pm 0.1$ & $0.2 \pm 0.1$ & $0.6 \pm 0.1$ & $6.7 \pm 2.8$ \\
\hline THRX-195518, $\mathrm{K}_{\mathrm{i}}, \mathrm{nM} \pm \mathrm{S} / \mathrm{D}$. & $1.2 \pm 0.2$ & $2.0 \pm 0.4$ & $1.8 \pm 0.4$ & $1.6 \pm 0.2$ & $17.0 \pm 2$ \\
\hline
\end{tabular}

$\mathrm{K}_{\mathrm{i}}$, inhibition binding constant; $\mathrm{mAChR}$, muscarinic acetylcholine receptor.

${ }^{a}$ Hegde et al. (2018). 


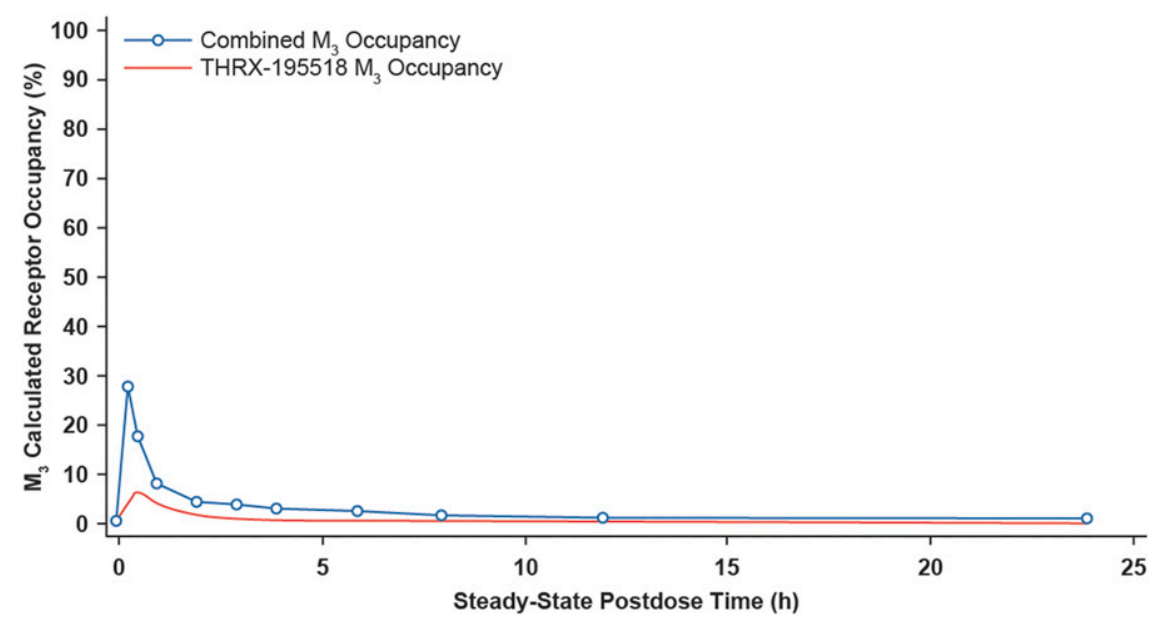

Fig. 4. $\mathrm{M}_{3}$ Calculated receptor occupancy at steady-state systemic exposures after $175 \mu \mathrm{g}$ inhaled administration of revefenacin.

Unchanged revefenacin accounted for $52 \%$ and $13 \%$ of total circulating radioactivity in plasma after intravenous and oral administration, respectively. The major metabolic pathway after intravenous and oral administration was hydrolysis of revefenacin to THRX195518, although additional pathways, including N-dealkylation, generated five further metabolites. Two main circulating metabolites were observed in plasma: THRX-195518 accounted for $14.3 \%$ of the total radioactivity after intravenous administration, and THRX195518 (hydrolysis) and THRX-697795 (N-dealkylation and reduction of revefenacin) each comprised $12.5 \%$ of total radioactivity after the oral dose. THRX-195518 exceeded the $10 \%$ threshold for circulating metabolites as outlined in the International Council for Harmonisation of Technical Requirements for Pharmaceuticals for Human Use M3 (R2) and Food and Drug Administration Safety Testing for Drug Metabolites guidance documents after intravenous administration, which is used as a surrogate for the inhaled route of administration (Food and Drug Administration, 2010; https://www. fda.gov/media/72279/download). However, adequate animal exposure in the toxicology program was demonstrated for THRX-195518 during the course of development of revefenacin (data on file), and thus no additional studies were conducted. Revefenacin was excreted unchanged in pooled feces at $27.2 \%$ and $66.8 \%$ of the administered dose after intravenous and oral administration, respectively. THRX195518 was the only metabolite excreted in feces at $>5 \%$ of the administered dose for either dosing route.

The hydrolysis of revefenacin to THRX-195518 represents the major metabolic pathway and raises questions with regard to the mechanism of hydrolysis and the potential for drug-drug interactions. A number of specific and nonspecific hydrolases have been implicated in the hydrolysis of drugs in various organs, including liver and intestine, and in blood and plasma (Fukami and Yokoi, 2012). Human carboxylesterases (hCES1 and hCES2) have been relatively well studied and are known to catalyze the hydrolysis of amides to the corresponding carboxylic acid (Di, 2019). Revefenacin exhibits significant conversion to THRX-195518 in human hepatocytes (https://www.accessdata.fda. gov/drugsatfda_docs/nda/2018/2105980rig1s000PharmR.pdf), suggesting that hCES1 (high expression in human liver) may play a role in its conversion in the liver. Studies to evaluate the potential of hCES1 to catalyze formation of THRX-195518 have not been conducted to date. However, the general lack of reported clinically significant drug-drug interactions for substrates of hCES or other hydrolase enzymes (Di, 2019) and low contribution of oxidative CYP-based metabolism for revefenacin $(<5 \%$ contribution of M8, M9, and M10 excreted after intravenous administration) indicate that the specific enzymes responsible for metabolism of revefenacin are unlikely to result in clinically significant drug-drug interactions.

The pharmacological properties of THRX-195518 showed moderate binding affinity for the five human muscarinic acetylcholine receptors. By comparison, revefenacin exhibited high affinity for all five muscarinic receptor subtypes (Hegde et al., 2018). Interestingly, the PK profile of THRX-195518 after nebulized administration in patients with COPD differs from that observed in healthy volunteers. Plasma exposure to THRX-195518 in patients with COPD is approximately 4-fold higher than that of revefenacin (Quinn et al., 2018). The higher exposure to THRX-195518 in patients with COPD raises the question of whether it may contribute to any systemic pharmacological effects despite its 10-fold lower potency at the $\mathrm{M}_{3}$ receptor. It should be noted that the prescribing information for revefenacin (YUPELRI, 2018) describes a range of potency for THRX-195518 that indicates it is 3-fold to 10 -fold less potent than parent revefenacin. However, the potency for revefenacin was underestimated in a pilot study that suggested only a 3fold difference in potency due to an inappropriately short incubation time $(\approx 1$ hour) compared with the longer incubation times $(\approx 16$ hours) used in the definitive studies (Hegde et al., 2018). A slowly dissociating ligand, such as revefenacin, requires longer incubation periods to achieve equilibrium with the target, and thus the 10-fold difference in potency between THRX-195518 and revefenacin at the M3 receptor remains the most robust assessment of relative potency and was used in the fractional occupancy analysis. Unbound clinical exposure of both revefenacin and THRX-195518 was used in the fractional receptor occupancy model to assess the likely contribution of each species to systemic antimuscarinic effects. This analysis demonstrated that the THRX-195518 $\mathrm{M}_{3}$ occupancy at the therapeutic dose of revefenacin $(175 \mu \mathrm{g})$ was negligible and did not exceed $10 \%$ at any time point postdose. These results imply that any systemic antimuscarinic effects observed after dosing of revefenacin primarily result from exposure to revefenacin as opposed to the THRX-195518 active metabolite. Overall, the calculated levels of combined $\mathrm{M}_{3}$ receptor occupancy for revefenacin and THRX-195518 at the therapeutic dose level were low, transient, and not expected to result in clinically meaningful systemic antimuscarinic pharmacodynamic effects consistent with the reported AE profile for revefenacin.

\section{Conclusions}

Revefenacin had low absolute bioavailability $(<3 \%)$ after oral administration. The major metabolic pathway was hydrolysis to THRX-195518, and both revefenacin and THRX-195518 underwent 
hepatic-biliary and fecal elimination after oral or intravenous administration, with negligible renal excretion. THRX-195518 has a 10-fold lower binding affinity for the $\mathrm{M}_{3}$ receptor relative to revefenacin, with receptor occupancy analysis suggesting a minimal contribution of THRX-195518 to systemic pharmacology relative to revefenacin. Single intravenous or oral doses of revefenacin were generally well tolerated.

\section{Acknowledgments}

Medical writing and editorial support funded by Theravance Biopharma US, Inc. (South San Francisco, CA) were provided by Esther Berkowitz, Gautam Bijur, and Frederique H. Evans of Ashfield Healthcare Communications.

\section{Authorship Contributions}

Participated in research design: Bourdet, Yeola, Hegde, Colson, Barnes, Borin.

Conducted experiments: Bourdet, Hegde, Borin.

Contributed new reagents or analytic tools: Bourdet, Hegde, Colson, Borin. Performed data analysis: Bourdet, Hegde, Borin.

Wrote or contributed to the writing of the manuscript: Bourdet, Yeola, Hegde, Colson, Barnes, Borin.

\section{References}

Al-Jayyoussi G, Price DF, Francombe D, Taylor G, Smith MW, Morris C, Edwards CD, Eddershaw P, and Gumbleton M (2013) Selectivity in the impact of P-glycoprotein upon pulmonary absorption of airway-dosed substrates: a study in ex vivo lung models using chemical inhibition and genetic knockout. J Pharm Sci 102:3382-3394.

Berg T, Hegelund-Myrbäck T, Öckinger J, Zhou XH, Brännström M, Hagemann-Jensen M Werkström V, Seidegård J, Grunewald J, Nord M, et al. (2018) Expression of MATE1, P-gp, OCTN1 and OCTN2, in epithelial and immune cells in the lung of COPD and healthy individuals. Respir Res 19:68.

Berg T, Hegelund Myrbäck T, Olsson M, Seidegård J, Werkström V, Zhou XH, Grunewald J, Gustavsson L, and Nord M (2014) Gene expression analysis of membrane transporters and drug-metabolizing enzymes in the lung of healthy and COPD subjects. Pharmacol Res Perspect 2:e0054.

Borin MT, Barnes CN, Darpo B, Pendyala S, Xue H, and Bourdet DL (2020) Revefenacin, a longacting muscarinic antagonist, does not prolong QT interval in healthy subjects: results of a placebo- and positive-controlled thorough QT study. Clin Pharmacol Drug Dev 9:130-139.

Di L (2019) The impact of carboxylesterases in drug metabolism and pharmacokinetics. Curr Drug Metab 20:91-102.

Donohue JF, Kerwin E, Sethi S, Haumann B, Pendyala S, Dean L, Barnes CN, Moran EJ, and Crater G (2019a) Maintained therapeutic effect of revefenacin over 52 weeks in moderate to very severe Chronic Obstructive Pulmonary Disease (COPD). Respir Res 20:241.
Donohue JF, Kerwin E, Sethi S, Haumann B, Pendyala S, Dean L, Barnes CN, Moran EJ, and Crater G (2019b) Revefenacin, a once-daily, lung-selective, long-acting muscarinic antagonist for nebulized therapy: safety and tolerability results of a 52-week phase 3 trial in moderate to very severe chronic obstructive pulmonary disease. Respir Med 153:38-43.

Fallon JK, Houvig N, Booth-Genthe CL, and Smith PC (2018) Quantification of membrane transporter proteins in human lung and immortalized cell lines using targeted quantitative proteomic analysis by isotope dilution nanoLC-MS/MS. J Pharm Biomed Anal 154:150-157.

Ferguson GT, Feldman G, Pudi KK, Barnes CN, Moran EJ, Haumann B, Pendyala S, and Crater G (2019) Improvements in lung function with nebulized revefenacin in the treatment of patients with moderate to very severe COPD: results from two replicate phase III clinical trials. Chronic Obstr Pulm Dis (Miami) 6:154-165.

Food and Drug Administration (2010) International Conference on Harmonisation; guidance on M3(R2) nonclinical safety studies for the Conduct of Human Clinical Trials and Marketing Authorization for Pharmaceuticals; availability. Notice. Fed Regist 75:3471-3472.

Fukami T and Yokoi T (2012) The emerging role of human esterases. Drug Metab Pharmacokinet 27:466-477.

Hamilton RA, Garnett WR, and Kline BJ (1981) Determination of mean valproic acid serum level by assay of a single pooled sample. Clin Pharmacol Ther 29:408-413.

Harrell AW, Siederer SK, Bal J, Patel NH, Young GC, Felgate CC, Pearce SJ, Roberts AD, Beaumont C, Emmons AJ, et al. (2013) Metabolism and disposition of vilanterol, a longacting $\beta(2)$-adrenoceptor agonist for inhalation use in humans. Drug Metab Dispos 41: 89-100

Harrell AW, Wilson R, Man YL, Riddell K, Jarvis E, Young G, Chambers R, Crossman L, Georgiou A, Pereira A, et al. (2019) An innovative approach to characterize clinical ADME and pharmacokinetics of the inhaled drug nemiralisib using an intravenous microtracer combined with an inhaled dose and an oral radiolabel dose in healthy male subjects. Drug Metab Dispos 47:1457-1468

Hegde SS, Pulido-Rios MT, Luttmann MA, Foley JJ, Hunsberger GE, Steinfeld T, Lee T, Ji Y, Mammen MM, and Jasper JR (2018) Pharmacological properties of revefenacin (TD-4208), a novel, nebulized long-acting, and lung selective muscarinic antagonist, at human recombinant muscarinic receptors and in rat, guinea pig, and human isolated airway tissues. Pharmacol Res Perspect 6:e0400.

Pudi KK, Barnes CN, Moran EJ, Haumann B, and Kerwin E (2017) A 28-day, randomized, doubleblind, placebo-controlled, parallel group study of nebulized revefenacin in patients with chronic obstructive pulmonary disease. Respir Res 18:182

Quinn D, Barnes CN, Yates W, Bourdet DL, Moran EJ, Potgieter P, Nicholls A, Haumann B, and Singh D (2018) Pharmacodynamics, pharmacokinetics and safety of revefenacin (TD-4208), a long-acting muscarinic antagonist, in patients with chronic obstructive pulmonary disease (COPD): results of two randomized, double-blind, phase 2 studies. Pulm Pharmacol Ther 48: 71-79.

Roffey SJ, Obach RS, Gedge JI, and Smith DA (2007) What is the objective of the mass balance study? A retrospective analysis of data in animal and human excretion studies employing radiolabeled drugs. Drug Metab Rev 39:17-43.

YUPELRI $^{\mathrm{TM}}$. (2018) YUPELRI ${ }^{\mathrm{TM}}$ (revefenacin) inhalation solution, for oral inhalation. Mylan Inc., Canonsburg, PA.

Address correspondence to: David L. Bourdet, Theravance Biopharma US Inc., 901 Gateway Blvd., South San Francisco, CA 94080. E-mail: DBourdet@ theravance.com 